\title{
Post-Tridentine Catholic Piety and Forms of Devotional Practices in the Polish-Lithuanian Commonwealth
}

The issue of post-Tridentine Catholic piety has concerned many scholars in Poland and has become a focus of a number of studies. Humanism: Humanist Ideas, Currents and Paradigms in Polish Culture and Culture of the First Commonwealth in Dialogue with Europe: Hermeneutics of Values are two international research projects involving Polish and foreign academics. The projects resulted in the publication of several important volumes, three of which deserve special mention: Humanitas and Christianitas in Polish Culture edited by M. Hanusiewicz-Lavallee (Warszawa 2009), Forming Catholic Culture in the

\footnotetext{
${ }^{1}$ Katarzyna Kaczor-Scheitler, PhD — assistant professor at the Department of Old Literature, Editing and Auxiliary Sciences at the University of Lodz. Author of books: Mistycyzm hiszpański w piśmiennictwie polskich karmelitanek XVII i XVIII wieku (Spanish Mysticism in the Literature of $17^{\text {th }}$ and $18^{\text {th }}$-Century Polish Carmelites) (2005); Marianna Marchocka a św. Teresa z Avila (Marianna Marchocka and St. Theresa of Avila) (2009); Perswazja w wybranych medytacjach siedemnastowiecznych z klasztoru norbertanek na Zwierzyńcu (Persuasion in Selected 17 $7^{\text {th }}$-Century Meditations from the Norbertine Monastery in Zwierzyniec) (2016). Co-editor of volumes of collected essays: Piśmiennictwo zakonne w dobie staropolskiej (Religious Writing in Old Poland) (2013) and Piotr Skarga - w czterechsetlecie śmierci (Piotr Skarga - on the 400 th Anniversary of His Death) (2013). Author of works published in numerous conference proceedings and special volumes. Publishes her articles in Polish and foreign journals: "Acta Universitatis Lodziensis. Folia Litteraria Polonica", "Analecta Praemonstratensia", "Communio. Międzynarodowy Przegląd Teologiczny", "Czytanie Literatury. Łódzkie Studia Literaturoznawcze", "Pamiętnik Literacki”, "Poznańskie Studia Polonistyczne. Seria Literacka", "Poznańskie Studia Teologiczne", "Prace Polonistyczne", "Przegląd Powszechny", "Respectus Philologicus", "Ruch Literacki", "Studia Monastica", "Świat i Słowo", "Świat Tekstów. Rocznik Słupski", "Tematy i Konteksty". Main areas of interest: old religious literature, especially occasional, ascetic-mystical and meditative literature; e-mail: katarzyna.kaczor-scheitler@uni.lodz.pl. ORCID: 0000-0003-3955-138X.
} 
Post-Tridentine Era: The Universality and National Character of Polish Catholicism edited by J. Dąbkowska-Kujko (Warszawa 2016) and Spiritual Paths of Polish Catholicism in the $17^{\text {th }}$ Century edited by A. Nowicka-Jeżowa (Warszawa 2016). The last two volumes are a particular testimony to very dynamic scholarly examination of the post-Tridentine era in historic Poland. The authors in the first volume discuss the issues of confessional identity of Catholic laity in post-Tridentine Poland (M. Hanusiewicz-Lavallee), the growing popularity of Calvaries and resulting theatralization of religious practices (M. Prejs), Protestant conversions to Catholicism (K. Meller), the concept of the unity of the Church and the idea of Catholic Poland in the works of post-Tridentine writers (E. Buszewicz), the role of post-Tridentine censorship in Poland (P. Buchwald-Pelcowa), and the new model of sainthood (M. Lenart). The other volume synthetizes and problematizes the spirituality of religious orders established or reformed in the post-Tridentine era. All these publications have had a significant impact on how post-Tridentine developments in Poland are currently viewed and interpreted ${ }^{2}$. Some of the issues discussed in them have become the central themes of the present article. It provides an overview of the present understanding of the post-Tridentine Catholic piety and indicates areas that need further research. The article describes various forms of the cult of the Passion of Christ, Calvarian devotions, ascetic practices, Marian piety, the cult of saints, and hagiography. An attempt is made to summarize the main findings from recent studies and provide extensive bibliography of the post-Tridentine Polish piety.

Religious practices and forms of piety in Poland after the Council of Trent were rooted deeply in late medieval traditions. The goal of Catholic reform was to 'conduct doctrinal purification of common devotional practices, introduce new forms of piety, catechize, and develop certain cults', but, at the same time, it

\footnotetext{
2 See: Humanitas $i$ christianitas $w$ kulturze polskiej, red. M. Hanusiewicz-Lavallee, t. 4, Warszawa 2009 (esp. the article by A. Czechowicz, Katolicyzm sarmacki, pp. 191-222 and chapters on post-Tridentine religious, educational and aesthetic 'evolution' initiated by the Jesuit order as well as chapters on the Reformation and humanism); Formowanie kultury katolickiej $w$ dobie potrydenckiej, red. J. Dąbkowska-Kujko, t. 6, Warszawa 2016 (esp. chapters on the phenomenon of the Catholic renewal); Drogi duchowe katolicyzmu polskiego XVII wieku, red. A. Nowicka-Jeżowa, t. 7, Warszawa 2016 (esp. chapters presenting the findings of studies on Polish Catholicism in the post-Tridentine era). For more about post-Tridentine piety, see: B. Popiołek, Wartości religijne w mentalności kobiet z pogranicza Rzeczypospolitej w czasach saskich, in: Religijność na polskich pograniczach w XVI-XVIII wieku, red. D. Dolański, Zielona Góra 2005, pp. 287-300; A. Nowicka-Struska, Obrazy kobiety i kobiece wzorce osobowe w siedemnastowiecznych kazaniach pogrzebowych autorstwa karmelitów bosych, "Wschodni Rocznik Humanistyczny" 3 (2006), p. 57-68; A. Nowicka-Struska, Ex fumo in lucem. Barokowe kaznodziejstwo Andrzeja Kochanowskiego, Lublin 2008, pp. 108-115; K. Sokołowska, Świeckich drogi do świętości w hagiografii sarmacko-barokowej, Poznań 2008; U. Kicińska, Pobożność szlachcianki w świetle polskich drukowanych mów pogrzebowych XVII wieku, "Folia Historica Cracoviensia" 18 (2012), pp. 213-237.
} 
drew heavily upon earlier traditions, 'very popular in the $16^{\text {th }}$ century among the general populace' 3 . Baroque spirituality was thus a combination of nova et vetera, of the new and the old, which were all integrated into the programme of Church reform and renewal in the post-Tridentine era ${ }^{4}$. Religious culture of that period was influenced by the implementation of reform decrees, creation of new religious orders and increased concern for pastoral care.

Devotions to the Passion of Christ, which had already been common in the Middle Ages, gained new popularity after the Council of Trent and became a characteristic feature of Polish Counter-Reformation religiosity ${ }^{5}$. Devotion to Christ's Passion was expressed in a wide range of rites, and pious, poetic and ascetic practices. Among many manifestations of popular piety, there was the cult of Arma Christi, relics of the Cross and miraculous crucifixes. Churches which possessed relics of the Holy Cross (e.g. in Lublin) attracted crowds of pilgrims ${ }^{6}$. The cult of the Passion of Christ had its liturgical expression in the form of votive Masses of the Passion of the Lord and of the Holy Cross, meditating the Sorrowful Mysteries of the Rosary, and praying the Chaplet of the Five Wounds of Jesus. Believers were encouraged to contemplate the Passion of Christ during each Mass they attended. The Stations of the Cross was a very popular devotion; many translations and adaptations of the Hours of the Passion ascribed to St Bonaventure were also made available. At the beginning of the $18^{\text {th }}$ century, in 1707, Wawrzyniec Stanisław Benik, a priest and missionary in Warsaw, collected and published Gorzkie Żale (Lenten Lamentations). This paraliturgical devotion had developed at the end of the previous century and was

3 J. Kłoczowski, L. Müllerowa, J. Skarbek, Zarys dziejów Kościoła katolickiego w Polsce, Kraków 1986, pp. 139.

${ }^{4}$ For a discussion of the Catholic reform, see: ibidem, pp. 91-95; S. Litak, Od reformacji do oświecenia. Kościót katolicki w Polsce nowożytnej, Lublin 1994, pp. 8-108.

${ }^{5}$ On the cult of the Passion of Christ after the Council of Trent, see: J. Smosarski, Z misteryjnej tradycji, "Przegląd Powszechny" 5 (1982), pp. 196-209; J. Stręciwilk CP, Męka Pańska w polskiej literaturze barokowej, in: Męka Chrystusa wczoraj i dziś, red. H.D. Wojtyska CP, J.J. Kopeć CP, Lublin 1981, pp. 102-119; H.D. Wojtyska CP, Męka Chrystusa w religijności polskiej XVI-XVIII wieku, in: ibidem, pp. 61-79; D. Künstler-Langner, Człowiek i cierpienie w poezji XVII wieku. Filozoficzne i religijne inspiracje, in: Literatura polskiego baroku w kregu idei, red. A. Nowicka-Jeżowa, M. Hanusiewicz, A. Karpiński, Lublin 1995, pp. 257-269; M. Korolko, „, Mąż Boleści” $w$ staropolskich pieśniach pasyjnych, in: Chrystus w literaturze polskiej, red. P. Nowaczyński, (Zakład Badań nad Literaturą Religijną, 25), Lublin 2001, pp. 43-57; L. Teusz, „Bolesna Muza nie Parnasu Góry, ale Golgoty”. Mesjady polskie XVII stulecia, Warszawa 2002; W. Pawlak, Bt. Stanisław Papczyński. Wśród barokowych kaznodziejów, in: S. Papczyński, Pisma pasyjne, wstęp W. Pawlak, M. Miotk CP, thum. R.R. Piętka MIC, Warszawa 2008, pp. 7-53; J.S. Gruchała, K. Panuś, Wprowadzenie, in: Kazania pasyjne, red. J.S. Gruchała, K. Panuś, Kraków 2014, pp. 7-26.

${ }^{6}$ See: L. Zalewski, Czastka Krzyża Chrystusowego w kościele św. Stanisława OO. Dominikanów, Lublin 1946. 
ascribed to the Fraternity of St Roch in the Holy Cross Church in Warsaw where it was performed for the first time in 1698. The devotion was held in the period of Lent. The earliest text of the Lamentations, published by the Fraternity in 1707 as A Bundle of Myrrh from the Garden of Gethsemane, or the Lamentation over the Bitter Passion of the Son of God, is currently held in the library of Discalced Carmelite Nuns in Cracow. The structure of the devotion followed the pattern of the devotion on the morning hour of Matins and included 'elements of the Mystery of the Passion with its passion hymns"

Seventeenth-century Passion piety expressed itself through Calvaries (monumental re-creations of Jerusalem), which were centres of the Tridentine renewal and reform with its emphasis on the centrality of contemplation of the Passion of Christ $^{8}$. The creators of Calvaries attempted to mimic the topography of Jerusalem in the times of Jesus. The first and the best known was Kalwaria Zebrzydowska. It was founded on 1 December 1602 by magnate Mikołaj Zebrzydowski, voivode of Cracow and great landowner in Małopolska region. During his lifetime, the complex consisting of the church, Bernardine monastery near Lanckorona and seventeen chapels was built. After his death, the project was continued and by the middle of the $17^{\text {th }}$ century about fifty buildings had been erected on the site?

The founder of the second oldest Polish Calvary (Kalwaria Pakoska) was Michał Działyński, inspired by a local parish priest Wojciech Kęsicki. Another similar project was Kalwaria Pacławska near Przemyśl. Founded in the middle of the $17^{\text {th }}$ century by Andrzej Maksymilian Fredro (1620-1679), castellan of Lviv and voivode of Podolia, it commemorated the Passion of Christ and the life of His Mother. Its administration was given over to the Conventual Franciscans, who had been engaged in its creation ${ }^{10}$. Kalwaria Pacławska consisted of 28 chapels connected by 'pilgrimage paths' (Pol. dróżki), as well as the church and

${ }^{7}$ M. Bańbuła, B. Bartkowski, Gorzkie żale, in: Encyklopedia katolicka, red. L. Bieńkowski et al., t. 5, Lublin 1989, col. 1310; see also H.D. Wojtyska CP, Męka Chrystusa..., pp. 61-79; S. Dąbrowski, „Pobudka” Gorzkich żali (Próby analizy i charakterystyki), “Znak” 35 (1983), pp. 960-965.

${ }^{8}$ See: Z. Bania, Kalwarie polskie w XVII wieku. Dzieje stosowania w Europie od X do końca XVII wieku uświęconych pasja Chrystusa miar jerozolimskich, Warszawa 1993; A. Mitkowska, Polskie kalwarie, Wrocław 2003.

9 See: H. Wyczawski, Kalwaria Zebrzydowska. Historia klasztoru bernardynów i kalwaryjskich dróżek, Kalwaria Zebrzydowska 1987. On the topic of Calvary prayer books, see: A. Pawlak, „Drogi Odkupienia...” Nabożeństwo pasyjne w Kościele polskim doby potrydenckiej na przykładzie Kalwarii Zebrzydowskiej, in: Seminaria staropolskie. Literatura w kontekstach kulturowych, red. R. Krzywy, Warszawa 1997, pp. 109-129.

${ }_{10}$ See: J. Kopeć, Kalwaria, in: Encyklopedia katolicka, t. 8, red. B. Migut, Lublin 2000, col. 414-420. 
fortified monastery ${ }^{11}$. There were many more Calvaries founded across the country (Wileńska, Żmudzka, Wejherowska, Góra Kalwaria near Warsaw) and in all of them 'attempts were made, in accordance with Baroque mentality, to achieve harmony between movement, vision, theatrical performance and authentic piety, in order to help people experience through their own bodies and senses the mystery of Christ's suffering and death' ${ }^{12}$. Booklets for pilgrims were also published, which served as simple guides to the holy places, explaining their ideological objectives and providing examples of devotional practices for the pilgrims to follow. One of such publications was Abraham Rożniatowski's Pamiatka krwawej ofiary Pana Zbawiciela naszego Jezusa Chrystusa (Commemoration of Our Saviour Jesus Christ's Bloody Sacrifice) printed in Cracow in 1610 as a guide to 'pilgrimage paths' in Kalwaria Zebrzydowska.

Calvaries served as locations for various devotions to the Passion of Christ, the Way of the Cross in particular. In Kalwaria Zebrzydowska, Passion devotions were inspired by Franciszek Dzielowski (b. 1622 or 1630 in Małopolska, d. 1681 in Cracow), definitor of Małopolska custody, minister provincial of the Bernardine order in Poland, author of ascetic writings ${ }^{13}$. In his work, Kalwaryja albo Nowe Jeruzalem na polach Zebrzydowskich zasadzone [...] krótko z fundamentu swego wywiedziona (Calvary or New Jerusalem in Zebrzydów, Kazimierz near Cracow 1669), Dzielowski described the history of the place and added: a guide for pilgrims praying at the stations of the Way of the Cross, a prayer to Our Lady of Kalwaria, and a panegyric in praise of the founder of Kalwaria Zebrzydowska ${ }^{14}$.

One of the ways of walking 'pilgrimage paths' in Calvaries was by attending re-enactments of Christ's Passion. Such Passion Plays were related to medieval 'sacred performances' and since the mid- $17^{\text {th }}$ century were becoming more and more elaborate. Their main objective was to 're-enact the sacred story, with the believers witnessing the events of the Passion of Christ staged in

11 See: J. Barcik, Kalwaria Pacławska, in: Encyklopedia katolicka, t. 8, red. B. Migut, col. $420-421$.

12 H.D. Wojtyska CP, Męka Chrystusa ..., p. 65. For more on this topic, see: J.J. Kopeć, Dzieje nabożénstwa Drogi Krzyżowej w Polsce, "Roczniki Teologiczno-Kanoniczne" 4 (1974), pp. 42-59; idem, Kalwarie i cykle Drogi Krzyżowej w kulturze polskiej oraz ich związi z topografia Jerozolimy, in: Jerozolima $w$ kulturze europejskiej, red. P. Paszkiewicz, T. Zadrożny, Warszawa 1995, pp. 225-240.

13 See: K. Kantak, Dzielowski Franciszek, in: Polski stownik biograficzny, red. W. Konopczyński, t. 6, Kraków 1948, p. 137; H.E. Wyczawski, Dzieje Kalwarii Zebrzydowskiej, Kraków 1947, pp. 156, 194, 216; B. Łukarska, Religijność sarmacka w przekazie piśmiennictwa polskiego XVII i XVIII wieku. Zarys monograficzny $i$ antologia tekstów źródłowych, Częstochowa 2018, p. 806.

14 B. Łukarska, Religijność sarmacka ..., pp. 241-243, 362. 
«authentic» locations in New Jerusalem, and the idea of co-suffering extended to all participants' ${ }^{15}$.

Late medieval Polish religiosity was characterised by the dolorist approach to the Passion of Christ. Dolorism, a current in medieval art, and pietà as its most characteristic type of devotional image ${ }^{16}$, were the ways of representing the sufferings of the Crucified and His Sorrowful Mother. The cult of the Passion also gave rise to the popularity of depictions of Pensive Christ. This way of portraying Jesus dates back to medieval Passion cycles. He is shown sitting in meditation, with His head supported by His hand. The image is supposed to emphasise Christ's physical and spiritual suffering. The Pensive Christ is also depicted on Golgotha, stripped of His garments, accompanied by His Sorrowful Mother (Occursus Mariae), or, in some other images, by His executioners and other people ${ }^{17}$.

In the post-Tridentine era, devotion to the Passion of Christ was promoted by confraternities. They started developing in the $14^{\text {th }}$ century and prospered in the $16^{\text {th }}$ and $17^{\text {th }}$ centuries. Among the most important were the Archconfraternity of the Lord's Passion, the Confraternity of the Five Wounds of Jesus Christ at monasteries of the Canons Regular of the Lateran, the Confraternity of the Crucified Redeemer at the Marian parish in Cracow, the Confraternity of Lord's Passion in Lviv. There was also a number of Christ-centric confraternities: the Confraternity of the Most Holy Name of Jesus, the Confraternity of the Transfiguration of the Lord, the Confraternity of Jesus of Nazareth, and the Confraternity of the Sacred Heart of Jesus. The cult of the Name of Jesus was disseminated in $17^{\text {th }}$-century Poland by Dominican monks ${ }^{18}$.

The faithful were invited to join the Passion of Jesus by contemplating His suffering (meditatio) in order to enhance the intimate, internal experience of His pain (compassio), and subsequently imitate Him (imitatio). The state of perfect love for Jesus could only be obtained by standing by Him at the foot of the cross and by following the example of the Crucified. Spirituality rooted in the mystery

15 J.S. Gruchała, Wprowadzenie do lektury, in: A. Rożniatowski, Pamiątka krwawej ofiary Pana Zbawiciela naszego Jezusa Chrystusa, red. J.S. Gruchała, (Biblioteka Pisarzy Staropolskich, 27), Warszawa 2003, p. 8. See: J. Lewański, Trzy modele religijnych widowisk XVII w. w Polsce, in: Dramat i teatr religijny w Polsce, red. I. Sławińska, W. Kaczmarek, Lublin 1991, pp. 33-45.

16 See: E. Panofsky, Imago Pietatis. Przyczynek do historii typów przedstawieniowych Mąż Boleści i Maria Pośredniczka, in: E. Panofsky, Studia z historii sztuki, tłum. i red. J. Białostocki, Warszawa 1971, pp. 95-121.

17 See: T. Dobrzeniecki, Chrystus Frasobliwy w literaturze średniowiecznej, "Biuletyn Historii Sztuki” 30 (1968) 3, pp. 279-299; idem, Wybrane zagadnienia ikonografii pasyjnej w sztuce polskiej, in: Męka Chrystusa wczoraj i dziś, red. H.D. Wojtyska CP, J.J. Kopeć CP, Lublin 1981, pp. 131-151.

18 See: J. Flaga, Bractwa religijne w Rzeczypospolitej $w$ XVII $i$ XVIII wieku, Lublin 2004, pp. $120-124$. 
of the Passion is a feature of the writings of St Bonaventure (1221-1274), who is often referred to as the Doctor of the Passion and the Doctor of the Crucified Word. He claimed that the only way to God was 'from Christ and through Christ to Christ'. He also added that 'there is no other way [to contemplation], but through the burning love of the Crucified Christ' ${ }^{19}$. The way leading to the mystical union was described in St Bonaventure's two great treatises on the Passion: Lignum Vitae (Tree of Life) and Vitis Mystica (Mystical Life or Treatise on the Lord' Passion). In another treatise, De Perfectione Vitae ad Sorores, he addressed nuns:

Therefore, oh handmaid, with the feet of your affections approach the wounded Jesus, to Jesus crowned with thorns, to Jesus fixed to the gibbet of the cross. And with blessed Thomas do not look only at the impression of the nails in his hands. And do not only put your finger in the place of the nails and your hand in his side. Rather, through the door of his side enter as far as the heart of Jesus himself. Transformed there into Christ by the most ardent love of the Crucified, fixed by the nails of divine fear, pierced to the heart by the lance of love, pierced through by the sword of interior compassion, you then seek nothing else but to die on the cross with Christ. Then you may cry out with the Apostle Paul and say, "With Christ I have been crucified on the cross. It is no longer I who live. Indeed Christ lives in me"20.

According to Franciscan thought, to imitate Christ, one must constantly follow Him and carry one's own cross. Imitating the Passion of Christ was an important element of the spirituality of many medieval renowned Franciscan nuns and mystics: Margaret of Cortona, Clare of Montefalco and Angela of Foligno as well as many pious clergymen of that time ${ }^{21}$. In their type of Passion Spirituality, they put emphasis mainly on the cult of the Cross, love for Christ the Merciful, veneration of His wounds, blood and sufferings ${ }^{22}$. The love for God expressed through the veneration of Christ's Wounds and Heart was also characteristic of Cistercian

19 J.J. Kopeć CP, Nurt pasyjny w średniowiecznej religijności polskiej, in: Męka Chrystusa wczoraj i dziś, red. H.D. Wojtyska CP, J.J. Kopeć CP, Lublin 1981, p. 46.

${ }^{20}$ On the Perfection of Life for Sisters or De perfectione vitae ad sorores, transl. P. Hanbridge OFM Cap, https://napcc.net/images/uploads/documents/De_perfectione_vitae.pdf [access: 11.06.2020]. See also: S.C. Napiórkowski, Chrystocentryzm myśli św. Bonawentury, "Roczniki Teologiczno-Kanoniczne" 21 (1974) 2, pp. 23-24.

21 J.J. Kopeć CP, Męka Pańska w religijnej kulturze polskiego średniowiecza. Studium nad pasyjnymi motywami i tekstami liturgicznymi, (Textus et Studia, t. 3), Warszawa 1975, pp. 92-101.

22 See: W. Wydra, Miejsce Władystawa z Gielniowa $w$ kształtowaniu się średniowiecznej poezji religijnej, in: Literatura i kultura późnego średniowiecza w Polsce, red. T. Michałowska, Warszawa 1993, pp. 69-82. 
spirituality, akin to Franciscan piety, which is exemplified by the mystical experiences of St Mechthild (d. 1299) and St Gertrude the Great (d. 1302) ${ }^{23}$.

The cult of the Passion became influential also in the spirituality of the Dominicans, who had exhibited devotion to Christ's Wounds and Instruments of the Passion (Arma Christi) since the Middle Ages. The cult of the Crown of Thorns was probably popularized in medieval Poland by the Dominicans, and later by the Cistercians. Attempts were made at that time to introduce the feast of the Crown of Thorns in accordance with the Dominican tradition. Traces of these actions are visible in liturgical books in later periods. Analysis of texts for votive masses of the Crown of Thorns reveals the presence of numerous elements of Dominican tradition. Moreover, it confirms the crucial role of mendicant orders in shaping and development of Polish religiosity ${ }^{24}$. Promoting devotion to Christ's Passion was one of the ordinary duties of all medieval preachers ${ }^{25}$, but the Dominicans made it the central theme in their preaching. The early $14^{\text {th }}$-century collection of sermons by Peregryn of Opole exemplifies this trend ${ }^{26}$.

In the post-Tridentine era, one of the extreme ways of expressing devotion to Christ's Passion was the practice of flagellation as a way of experiencing the spiritual unity with Christ. This form of piety with its drastic methods of penance had developed in the Middle Ages. It provided an opportunity for a deeper understanding of the suffering of Christ and met the believers' desire to imitate Him. In monastic circles it was also a form of ascesis. The contemplation of Christ's Passion was to be accompanied by the desire for full participation in it.

In the opinion of the clergy, although ascetism should be practised by all Christians, it should be most strongly recommended to members of religious orders. The ideal emphasizing the rigorous monastic life was, however, more characteristic of the Middle Ages than of the early modern period ${ }^{27}$. Harsh devotional practices were part of spiritual life of some medieval mystics. St Bridget of Sweden (d. 1373), for instance, combined meditation of the Passion with such prac-

${ }^{23}$ W. Lampen, De spiritu S. Francisci in operibus S. Gertrudis Magnae, "Archivum Franciscanum Historicum” 19 (1926), pp. 733-752. Quoted in: J.J. Kopeć CP, Nurt pasyjny..., p. 48.

24 J.J. Kopeć CP, Przemiany ideowe pobożności pasyjnej na przykładzie kultu cierniowej korony Chrystusa, "Studia Theologica Varsaviensia" 10 (1972) 2, p. 191.

25 The Synod of Buda in 1279 instructed priests to teach the faithful about the Passion and Resurrection of Jesus Christ and promote the cult of the Crucified Christ. See: Starodawne prawa polskiego pomniki poprzedzone wywodem historyczno-krytycznym tak zwanego prawodawstwa wiślickiego Kazimierza Wielkiego, red. A.Z. Helcel, t. 1, Warszawa 1856, pp. 364-382.

26 J. Wolny, Laciński zbiór kazań Peregryna z Opola i ich związek z tzw. „Kazaniami gnieźnieńskimi”, in: Średniowiecze. Studia o kulturze, red. J. Lewański, t. 1, Warszawa 1961, p. 236.

${ }^{27}$ For more about this topic, see: M. Lenart, Spór Duszy z Ciałem i inne wierszowane spory w literaturze staropolskiej na tle tradycji średniowiecznej, Opole 2002, p. 106; B. Lukarska, Religijność sarmacka..., pp. 134-143. 
tices as kneeling, lying prostrate and severe fasting. In her devotion to Christ, St Catherine of Siena (d. 1380) focused on the 'veneration of the Saviour's precious Blood, Wounds and Heart ${ }^{28}$. The model of Franciscan asceticism was also promoted by some prominent representatives of the Polish Middle Ages, namely St Kinga, Blessed Salome and Blessed Jolenta ${ }^{29}$.

Mortification of the flesh as a form of piety was practiced also in the $17^{\text {th }}$-century. It consisted in such self-afflicted penances as wearing hairshirts or metal chains with inward-poking spikes, piercing oneself with nails and flagellation. Mortifying the body was practiced by monks, nuns and priests as well as the laity ${ }^{30}$. Its purpose was to deepen the experience of unity with the sufferings of Christ.

Jadwiga Stobieńska (1593-1649), the first Polish Discalced Carmelite nun, besought the Lord to let her share in His pain. She also desired to suffer for the sake of her fellow nuns, especially the sick and feeble ones ${ }^{31}$. Stobieńska 'contemplated Christ's Crown of Thorns and made her own crown of pins, which ran around her whole head and she would always wear it ${ }^{32}$. Another Discalced Carmelite nun, Marianna Marchocka (1603-1652), treated her long-lasting headaches as an opportunity to join Christ in his pain after being crowned with thorns. She also felt that her meditations of the Passion only increased her desire for more suffering ${ }^{33}$.

The biographer of Magdalena Mortęska (c. 1554-1631), the abbess and reformer of the Benedictine convent in Chełmno, wrote that ' [...] God endowed her with great piety in meditating Our Saviour's Passion, and she loved Him enormously $[\ldots]$. She also oftentimes conversed about this great mystery with

${ }^{28}$ J.J. Kopeć CP, Nurt pasyjny..., p. 52.

${ }^{29}$ See: O.M. Przybyłowicz, Pobożność przedstawicielek rodów panujących Europy Środkowej (XIII-pocz. XIV w.). Fenomen popularności franciszkanizmu: inspiracje - modele, in: Per mulierem... Kobieta $w$ dawnej Polsce - w średniowieczu $i$ w dobie staropolskiej, red. K. Justyniarska-Chojak, S. Konarska-Zimnicka, Warszawa 2012, pp. 67-87; K. Górski, A.M. Borkowska OSB, Historiografia zakonna a wzorce świętości w XVII w., (Textus et Studia, t. 15), Warszawa 1984.

${ }^{30}$ See: J. Tazbir, Święci, grzesznicy i kacerze. Z dziejów polskiej kontrreformacji, Warszawa 1959, pp. 151-154.

${ }^{31}$ F. Jaroszewicz, Matka świętych Polska albo żywoty świętych, błogosławionych, wielebnych, światobliwych, pobożnych Polaków i Polek. [...] Do druku podane R.P. 1767. Przedrukowane w Niemieckich Piekarach w Górnym Śląsku u Teodora Heneczka R.P. 1850, część I (Dzień XXVIII stycznia. Żywot Wielebnej Panny Anny od Jezusa Karmelitanki Bosej), p. 170.

32 Ibidem. For more about J. Stobieńska’s mystical experiences, see: K. Górski, Zarys dziejów duchowości w Polsce, Kraków 1986, pp. 138-140; K. Kaczor-Scheitler, Mistycyzm hiszpański w piśmiennictwie polskich karmelitanek XVII i XVIII wieku, Łódź 2005, pp. 59-91.

${ }_{33}$ Autobiografia mistyczna Matki Teresy od Jezusa, karmelitanki bosej (Anny Marii Marchockiej) 1603-1652, red. K. Górski, (Pisarze ascetyczno-mistyczni Polski, 2) Poznań 1939. See: K. Kaczor-Scheitler, Mistycyzm hiszpański..., pp. 92-129. 
other sisters ${ }^{34}$, who appeared to highly appreciate these dialogues. In the spirit of compassion, Mortęska explained why she did not seek praise., 'I understand [...] that at that time [whenever she was commended - K.K.S.] the slaps in the face and mockery my Lord suffered from his tormentors during the crowning with thorns are renewed' ${ }^{35}$. Kasper Drużbicki (1590-1662), apart from following severe discipline, used diverse implements such as 'whips, chains, hairshirts, and two iron combs, and one instrument studded with sharp nails, which were all found bloodstained after his death' ${ }^{36}$.

A variety of ascetic practices were used not only by members of religious orders, but also by the laity. Krystyna Potocka née Lubomirska (d. 1699) 'mortified her body with iron stripes, or disciplines, or rods' ${ }^{37}$. Elżbieta Gostomska (1573-1624), although 'by God's grace free of bodily passions, yet practiced self-mortification, coercing her body into subjugation to the spirit. At night she placed a crucifix on her bed, whereas she laid herself upon the rough cloth spread on bare boards or the floor. She disciplined herself three or four times a day ${ }^{38}$. The replication of Christ's suffering was supposed to be an introduction to the spiritual experience of His Passion; suffering as Christ suffered helped to fully understand the redemptive dimension of His Passion and Death.

In the post-Tridentine era, the descriptions of the Passion of Christ were vivid and detailed. They recorded meticulously all the lashes and wounds Jesus received when He was scourged and then crowned with thorns. All drops of blood and Christ's falls under the weight of the cross were punctiliously noted; all curses and jeers from the soldiers and cruelty of executioners during crucifixion were described in detail. Christ's loneliness on the cross was also emphasized. The cult of Arma Christi (the lance, the crown of thorns, the nails, the hammer, the pincers, the ladder, etc.), as well the cult of Christ's Wounds and Blood was propagated in Baroque literature. Devotional practices associated with the cult also developed. The post-Tridentine veneration of the Passion of Christ had considerable influence on religious culture. Passion spirituality found its expression in devotions, pilgrimages to the Holy Sepulchre in Jerusalem or Calvaries, foundations of churches, chapels and images of the Crucified.

A distinctive characteristic of Counter-Reformation piety was the immense popularity of the cult of the Mother of $\mathrm{God}^{39}$. It was connected with the arrival in

${ }^{34}$ Quoted in: K. Górski, Matka Mortęska, Kraków 1971, p. 120.

${ }^{35}$ Quoted in: ibidem, p. 171.

${ }^{36}$ Quoted in: J. Tazbir, Święci, grzesznicy i kacerze..., p. 151.

${ }^{37}$ Quoted in: ibidem, p. 153.

${ }^{38}$ Quoted in: ibidem (F. Jaroszewicz, Matka świętych ..., część I, pp. 262-263; część II, p. 222; część III, pp. 364-365).

${ }^{39}$ See: K. Głów, Chrystocentryzm kultu Maryi, in: W kierunku chrześcijańskiej kultury, red. B. Bejze, Warszawa 1978, pp. 279-300; S. Litak, Z dziejów kultu M. Boskiej Częstochowskiej 
Poland of several new religious orders with their specific rules, practices and devotions ${ }^{40}$. As an expression of the veneration of the Virgin Mary, wayside chapels were erected, and lamentations were composed (traces of which can be identified in Lenten Lamentations) $)^{41}$. The cult of Mary took the form of 'holy slavery'. The idea was propagated by the Jesuits in sermons and literature. In 1632, Franciszek Stanisław Foenicjusz published Mariae mancipium (A Slave of Mary), while in the same year his friend, Jan Chomętowski, translated the treatise into Polish as Pętko B. Panny Maryjej albo sposób oddawania sie jej za niewolnika ${ }^{42}$. 'Mary's slaves' wore a symbol of their commitment in the form of a chainlet, resembling shackles, with an inscription Ego Mancipium Mariae ${ }^{43}$. Meanwhile, the Carmelites disseminated the cult of the Immaculate Conception, which centred around special devotions and the Scapular Confraternity. The first association of this kind was founded in the 1630s in Cracow at St James's Church ${ }^{44}$.

The growing popularity of Marian devotion in $17^{\text {th }}$-century Polish Catholicism resulted in an increase in the role of Marian shrines, such as the Jasna Góra monastery in Częstochowa, and intense interest in pilgrimages to miraculous pictures of Our Lady. After the Swedish invasion of Poland and the unsuccessful siege of Jasna Góra, Częstochowa gained the status of a national Marian shrine ${ }^{45}$. In 1673, a new clerical religious congregation dedicated to the cult of the Virgin Mary was founded. It was the Congregation of Marian Fathers of the Immaculate Conception of the Most Blessed Virgin Mary. The founder of the congregation was Stanisław Papczyński (1631-1701). The aforementioned Kalwaria Zebrzydowska, apart from being the site of the cult of the Passion of Christ, in the $17^{\text {th }}$ century became also the place where the cult of Mary developed (Mary's paths, the feast of the Assumption of Mary, a miraculous picture of Our Lady). Apart from Częstochowa and Kalwaria Zebrzydowska, several other places, e.g. Piek-

w XVII-XVIII wieku. Sprawa zasięgu społecznego, in: Z zagadnień kultury chrześcijańskiej, red. B. Bejze, Lublin 1973, pp. 447-454; A. Nowicka-Jeżowa, Barok polski. Między Europa i sarmacja, cz. I: Profile i zarysy catości, Warszawa 2009-2011, pp. 180-185 (esp. Kult maryjny w katolicyzmie polskim XVII w.).

${ }^{40}$ Gradually, the Benedictine cult of Our Lady of the Assumption spread in Poland as well as the Franciscan cult of Our Lady of Sorrows and Our Lady of Joys, the Bernardine cult of the Immaculate Mary, the Carmelite cult of Our Lady of the Scapular, the Dominican cult of Our Lady of the Rosary. The Jesuit ascetic piety in the Marian sodalities was also becoming popular. See: J. Wojnowski CSSR, Rozwój czci Matki Bożej w Polsce, "Homo Dei” 26 (1957) 6, pp. 846-862.

${ }^{41}$ Ibidem, p. 850.

${ }^{42}$ For more about Jesuit authors who propagated the "holy slavery", see: K. Górski, Zarys dziejów duchowości w Polsce, pp. 170-171, 216-217.

${ }^{43}$ K. Górski, Zarys dziejów duchowości ..., pp. 170-171.

${ }^{44}$ J. Flaga, Bractwa religijne..., p. 99, 140.

${ }^{45}$ See: M. Pirożyński CSSR, Obrona Jasnej Góry w roku 1655, "Homo Dei” 26 (1957) 3, p. $359-368$. 
ary, Wiślica, Berdyczów, Święta Lipka, Bochnia, where miraculous images of Mary and the relics of saints were venerated, also became popular pilgrimage destinations ${ }^{46}$.

Scapular and Rosary confraternities as well as Marian sodalities, first founded by the Jesuits in the late $16^{\text {th }}$ century, enjoyed popularity ${ }^{47}$. In addition to the existing confraternities in Cracow and Lviv, new brotherhoods were created. The Rosary Confraternity came into being at the end of the $16^{\text {th }}$ century; the Confraternity of Consolation of the Blessed Virgin Mary was founded in 1604. Other confraternities included the Confraternity of the Holy Name of Mary, the Confraternity of Our Lady of Sorrows, and the Confraternity of the Annunciation to the Blessed Virgin Mary ${ }^{48}$.

Seventeenth-century model of Catholic religiosity manifested itself in the growth of Marian devotion. The Blessed Virgin was proclaimed the Queen of Poland. The feast of the Blessed Virgin Mary the Queen of Poland was added to the already celebrated feasts of the Most Holy Name of Mary and Our Lady of the Rosary. In 1696, the feast of Our Lady of Ransom was added to the calendar. In 1726, the feast of Mary of Mount Carmel, and in 1727, the feast of Our Lady of Sorrows were also introduced ${ }^{49}$.

Marian prayer books and Marian literature provide evidence of the popularity of the cult of Mary ${ }^{50}$. A best-selling Harfa duchowna (The Spiritual Harp, Cracow 1585) by Marcin Laterna (1552-1598), went through 25 editions by the end of the $17^{\text {th }}$ century ${ }^{51}$. An untitled prayer book containing Pozdrowienie Panny Maryjej, Godzinki o Pannie Maryjej (A Greeting to the Virgin Mary, Hours of the Virgin Mary, Cracow 1636) $)^{52}$ was in everyday use by the faithful. Marian devotion was also propagated through sermons and religious poetry ${ }^{53}$. In a volume titled Ogród panieński (Virgin's Garden), consisting of 1,600 couplets grouped

${ }^{46}$ J. Tazbir, Święci, grzesznicy i kacerze..., p. 146.

47 J.S. Bystroń, Dzieje obyczajów w dawnej Polsce. Wiek XVI-XVIII, t. 1, Warszawa 1994, p. 319; See: J. Muczkowski, Bractwa jezuickie i akademickie w Krakowie, Kraków 1845.

${ }^{48}$ J. Flaga, Bractwa religijne..., p. 91.

${ }^{49}$ On the liturgical veneration of Mary, see: B. Nadolski, Liturgika, t. 2: Liturgia i czas, Poznań 1991, pp. 137-142. For more on this topic in the context of Sarmatian religiosity, see: K. Sokołowska, Świeckich drogi do świętości ..., p. 41.

${ }^{50}$ See: K. Kaczor-Scheitler, O kulcie maryjnym Daniela Zielińskiego w świetle „Przedmowy” poprzedzającej ,,Szatę wzorzysta doskonałości” (1649), "Respectus Philologicus” 32 (37) (2017), pp. 21-22.

${ }^{51}$ See: S. Cieślak SJ, „Harfa duchowna” - modlitewnikowy bestseller jezuity Marcina Laterny (1552-1598), "Nasza Przeszłość" 93 (2000), pp. 23-48.

${ }_{52}$ The book is recorded in K. Estreicher, Bibliografia polska, t. 13, Kraków 1894, p. 248; ibidem, t. 22, Kraków 1908, pp. 481.

${ }^{53}$ See: S. Nieznanowski, Matka Boska w poezji baroku i czasów saskich, in: Matka Boska w poezji polskiej, t. 1: Szkice o dziejach motywu, red. M. Jasińska et al., Lublin 1959, pp. 37-61. 
in four parts, Wespazjan Kochowski mentioned traditional titles of Mary and used allegories, metaphors and similes referring to Her virtues. Titles given by Kochowski to Mary were rooted in the Bible, ancient and medieval Christian texts, as well as the realm of everyday life phenomena accessible to the poet ${ }^{54}$. Devotional books, prayer books and practical manuals for pilgrims, printed in pilgrimage destinations such as Jasna Góra also gained popularity ${ }^{55}$.

The cult of Mary and the accompanying veneration of Her sacred images was conducive to the increase in the role of religious songs, the cult of saints, and indulgences ${ }^{56}$. The Marian cult was strengthened via popular devotional practices, such as the Rosary, the Hours, the Rorate Masses. Although giving honour to Mary played an important role in the Polish religiosity of the $17^{\text {th }}$ century, it was still an integral part of 'the only worship that is rightly called Christian, because it takes its origin and effectiveness from Christ, finds its complete expression in Christ and leads through Christ in the Spirit to the Father'57. The Trinitarian and especially Christological perspective in the Baroque cult of Mary should be emphasized.

The triumph of the Counter-Reformation marked a new period in the development of hagiography. The veneration of the saints - one of the characteristic features of Catholicism, challenged by the Reformation (primarily by the Lutherans) - was revived at the end of the $16^{\text {th }}$ century. It was supposed to achieve two major goals: spreading the faith and providing role models for those who wanted to follow certain moral principles ${ }^{58}$. Counter-Reformation hagiographic works,

${ }^{54}$ See: A. Czyż, Sarmata - niewolnik Matki. Drużbicki, Montfort i „Ogród panieński” Kochowskiego, in: Barok — sarmatyzm — „Psalmodia”. Materiaty z konferencji zorganizowanej przez Zakład historii nowożytnej, Toruń 22-23 września 1993, red. K. Maliszewski, K. Obremski, Torun 1995, pp. 7-18; W. Pawlak, Twórczość Wespazjana Kochowskiego wobec popularnej literatury religijnej (na przykładzie „Ogrodu panieńskiego”), in: Sarmackie theatrum. II. Idee i rzeczywistość. Materiaty z konferencji naukowej, Katowice 9-11 grudnia 1998, red. R. Ocieczek, M. Barłowska, Katowice 2001, pp. 17-32; idem, O wyobraźni religijnej Wespazjana Kochowskiego - „Ogród Panieński”, in: Wespazjan Kochowski w kręgu kultury literackiej, red. D. Chemperek, Lublin 2003, pp. 161-183.

${ }_{55}$ The beginnings of the Jasna Góra printing house date back to 1692. Mikołaj Szotarewicz, the then Provincial of the Polish Paulines, was particularly involved in this undertaking. For more about devotional literature, especially Marian prayer books, from Jasna Góra, see: D. Bubel, Jasnogórskie piśmiennictwo dewocyjne w XVII-XVIII wieku. Recepcja modlitewnika Ksawerego Augustyna Rottera „Ucieczka grzeszników albo nabożny zasmuconych rekurs do dzielnej cudami Częstochowskiej Matki", "Biblioteka" 14 (2010), pp. 33-52.

${ }_{56}$ W. Müller, Trudne stulecie (1648-1750), in: Chrześsijaństwo w Polsce. Zarys przemian 966-1979, red. J. Kłoczowski, Lublin 1992, p. 289.

${ }^{57}$ Cited in: M. Bunson, Saint Pope Paul VI. Celebrating the 262 nd Pope of the Roman Catholic Church, Irondale, AL 2018, p. 77.

${ }^{58}$ H. Dziechcińska, Hagiografia, in: Stownik literatury staropolskiej. Średniowiecze - renesans - barok, red. T. Michałowska, B. Otwinowska, E. Sarnowska-Temeriusz, Wrocław 2002², 
contrary to their medieval predecessors, put greater emphasis on historically documented and reliable facts, while the poetics of wonder was less pronounced. The post-Tridentine hagiographers returning ad fontes were determined to base their new lives of saints on sources whose reliability was guaranteed by the gravissimi et probatissimi, the authors of irrefutable authority ${ }^{59}$.

The hagiographer's responsibility was to provide role models representing certain attitudes, moral values and approaches to interpreting human life. The saints in post-Tridentine hagiography were paragons of virtue and piety, models for the faithful to follow. A characteristic feature of $17^{\text {th }}$-century hagiographic writing was its markedly didactic tone. The lives of saints were intended to instil specific moral principles in a Catholic society ${ }^{60}$.

The $17^{\text {th }}$ century saw an increase in the popularity of the cult of Polish (St Adalbert, St Stanislaus of Szczepanów, St Stanislaus Kostka) as well as foreign saints (St Nicolaus, St Isidore). It was evidenced by a larger number of churches and altars dedicated to saints, proliferation of the feasts of saints (beatifications and canonisations), and publication of numerous prayers asking the saints for intercession ${ }^{61}$. There was also a tendency among hagiographers to emphasise similarities between the lives of Polish and other Christian saints. In Matka siwętych (The Mother of Saints), Florian Jaroszewicz wrote the biography of reverend Agnieszka Mikuliczówna, who spent three-quarters of a year in Carmelite novitiate disguised as a man. Having been detected, she invoked the case of St Euphrosyne of Alexandria, who dressed as a monk and lived in the male hermitage ${ }^{62}$.

The patron and role model for university teachers and students was St Jan Kanty $(1390-1473)^{63}$. Students in Jesuit colleges were encouraged to follow the example of St Stanislaus Kostka's life of mortification and self-denial. The cult of the saints flourished among members of religious orders, whose founders were often venerated as their patron saints. The Bernardines honoured St Anne, the Jesuits - St Ignatius of Loyola and Francis Xavier; the Piarists - St Joseph Calasanctius; the Franciscans - St Anthony. St Isidore the Farm Labourer, the

p. 301; eadem, Wzory osobowe, in: ibidem, p. 1066.

${ }^{59}$ A. Ceccherelli, Od Suriusa do Skargi. Studium porównawcze o „Żywotach świętych”, thum. M. Niewójt, Izabelin 2003, pp. 45, 46, 51. On post-Tridentine models of sainthood, see: B.M. Puchalska-Dąbrowska, Bohaterowie Wysp Brytyjskich jako wzorce świętości w hagiografii polskiej XVI-XVII wieku, Białystok 2009, pp. 32-39. For more about religious parenetical literature, see chapters in the post-conference volume: Wzorce osobowe $w$ dawnej literaturze $i$ kulturze polskiej, red. B.M. Puchalska-Dąbrowska, E.A. Jurkowska, Białystok 2018.

${ }^{60}$ H. Dziechcińska, Hagiografia ..., pp. 301-302.

${ }^{61}$ J.S. Bystroń, Dzieje obyczajów..., p. 323.

${ }^{62}$ F. Jaroszewicz, Matka świętych ..., pp. 413-415.

${ }^{63}$ J. Swastek, Jan Kanty, in: Encyklopedia katolicka, red. S. Wielgus et al., t. 7, Lublin 1997, col. 793-795. 
patron saint of farmers, was a model of pious and charitable life filled with prayer and work. In Polish hagiography, the story of St Isidore was supposed to justify the hard lot of peasants in the economy based on serfdom ${ }^{64}$.

A characteristic feature of post-Tridentine hagiography was its geographical universalism. Alongside historical universalism (figures of saints from different periods) and social universalism (saints from different social groups), it was intended to popularize the saints from different areas of the world, often distant and unknown ${ }^{65}$. In Żywoty świętych Starego i Nowego Zakonu (The Lives of the Saints from the Old and New Testaments), Piotr Skarga wrote about the martyrdom of the Jesuits in Japan and Brazil and about the cult of St Stanislaus Kostka in South America ${ }^{66}$.

In the era after the Council of Trent, the dominant ideal of religious perfection was that of monastic life, with its specific lifestyle and attitudes. Hagiography promoted certain models of morality, encouraged particular personality traits and provided patterns of ascetic life to follow, especially by novices and monks and nuns renewing their vows ${ }^{67}$. Vitae contemplativae as a model of Christian life was placed above all other. It was sanctioned by the Council of Trent ${ }^{68}$, which not only confirmed the official teaching of the Church, but also strengthened the officially propagated ideal of sainthood (which was easiest to achieve via conventual life ${ }^{69}$. The monastery was viewed by the contemporaries as a place where, as it was believed, living a holy life was easier than in a married, widowed or single state. Conventual life involved withdrawal from the world and choosing the spiritual path that would prepare one for eternal life.

${ }^{64}$ See: J. Tazbir, Święci, grzesznicy i kacerze..., p. 135-148; H. Dziechcińska, Hagiografia..., p. 302; B.M. Puchalska-Dąbrowska, Bohaterowie Wysp Brytyjskich..., p. 35. See also: J. Tazbir, Społeczna funkcja kultu Izydora „Oracza” w Polsce w XVII wieku, "Przegląd Historyczny” 46 (1955) 3, pp. 420-444.

65 B.M. Puchalska-Dąbrowska, Bohaterowie Wysp Brytyjskich ..., pp. 36-37.

66 J. Tazbir, Piotr Skarga - szermierz kontrreformacji, Warszawa 1983, p. 93.

${ }^{67}$ U. Borkowska OSU, Hagiografia polska (wiek XVI-XVIII), in: Dzieje teologii katolickiej $w$ Polsce, red. M. Rechowicz, cz. I, t. 2, Lublin 1975, pp. 488-489.

68 'If any one saith, that the marriage state is to be placed above the state of virginity, or of celibacy, and that it is not better and more blessed to remain in virginity, or in celibacy, than to be united in matrimony; let him be anathema' as quoted in: Kanony o sakramencie matzeństwa, in: Dokumenty Soborów Powszechnych. Tekst taciński, polski, t. 4: 1511-1870, oprac. A. Baron, H. Pietras, Kraków 2004, p. 719.

69 E.E. Wróbel CSFN, Życie religijne i zakonne w Polsce na przełomie XVI i XVII wieku, in: Cztery wieki Karmelitów Bosych w Polsce 1605-2005. Materiały z ogólnopolskiego sympozjum historyczno-teologicznego, Aula Collegium Novum, Uniwersytet Jagielloński, Kraków 21-22 listopada 2005, red. A. Ruszała OCD, Kraków 2005, p. 2. The author also wrote about the attractiveness of monastic life among women, as it offered an opportunity for independence and emancipation, gave the nuns a better education compared to lay women and increased public esteem for them. 
The collections of the lives of saints of the Church and Polish patron saints, as well as the biographies of individuals associated with local cults, also enjoyed popularity. The most notable included Żywoty świętych Starego i Nowego Zakonu na każdy dzień przez caly rok wybrane (Vilnius 1579) by Piotr Skarga (1536-1612), which went through as many as 33 editions ${ }^{70}$ and Roczne dzieje kościelne (Cracow 1603), translated by Piotr Skarga from Cesare Baronio's (1538-1607) ten-volume Annales ecclesiastici ${ }^{71}$. Another volume of Annales ecclesiastici was translated by Jan Kwiatkiewicz (1630-1703), a Jesuit, professor of rhetoric in Lublin and Lviv, ascetic writer ${ }^{72}$. One of the most valuable hagiographic texts is Baronio's Martyrologium Romanum, translated into Polish (Martyrologium Rzymskie, Cracow 1591) by Szymon Nikowski (1555-1591) — a Jesuit, translator, preacher and professor of rhetoric in Vilnius - in cooperation with Jakub Wujek ${ }^{73}$.

The cult of saints and the accompanying intensive development of hagiography in Poland in the post-Tridentine era played an important role in shaping the religious attitudes of the public. The themes and motifs that appeared in the lives of saints were gradually incorporated into sermons, dramas, songs and epic poetry. This was a characteristic feature of $17^{\text {th }}$-century literature to employ specific literary characters in order to indicate religious truths and moral concepts ${ }^{74}$.

The religious culture of Baroque Catholic Poland developed on two levels: elite and popular. It was closely related to people's mentality, shaped by both Tradition and the realities of the era. Post-Tridentine religiosity, drawing on the medieval tradition, gained a new, attractive artistic and dramatic setting in the Baroque era, which was evidenced not only by the growing popularity of the Passion and Christmas devotions, religious songs or formally, thematically and generically diversified prayer books, but also paraliturgical forms of worship, such as: mysteries, processions ${ }^{75}$, pilgrimages, brotherhoods, scapulars, etc.

70 See: A. Witkowska, J. Nastalska, Staropolskie piśmiennictwo hagiograficzne, t. 1: Słownik hagiografów polskich, Lublin 2007, pp. 226-228; E. Albingier, Męczennicy jezuiccy w „Żywotach świętych” Piotra Skargi, in: Piotr Skarga - w czterechsetlecie śmierci, red. M. Kuran et al., Łódź 2013, pp. 259-269.

71 See: J. Ślaski, Cesare Baronio $w$ przekładach polskich, in: Nurt religijny $w$ literaturze polskiego średniowiecza i renesansu, red. S. Nieznanowski, J. Pelc, Lublin 1994, pp. 365-393.

72 Encyklopedia wiedzy o jezuitach na ziemiach Polski i Litwy 1564-1995, red. L. Grzebień SJ, Kraków 2004, p. 351.

73 In a separate part of Martyrologium Rzymskie, S. Nikowski included the lives of the saints from the Breviary lessons. See: A. Witkowska, J. Nastalska, Staropolskie piśmiennictwo hagiograficzne..., pp. 166-167. For more about post-Tridentine hagiography, see: K. Kaczor-Scheitler, Perswazja $w$ wybranych medytacjach siedemnastowiecznych z klasztoru norbertanek na Zwierzyńcu, Łódź 2016, pp. 94, 273-275.

74 H. Dziechcińska, Hagiografia ..., p. 301.

75 For more about religious theatrum in $16^{\text {th }} / 17^{\text {th }}$-century Cracow, processions and other religious ceremonies, see: M. Rożek, Uroczystości w barokowym Krakowie, Kraków 1976, pp. 224-262. 
The piety of the faithful was emotional and external, often theatrical and demonstrative, but also supported by deep religious practices. The unwavering permanence of all 'forms of worship was undoubtedly conditioned by the fact that the religious heritage was an important emotive and identity factor ${ }^{776}$.

\section{Summary}

The article concerns the Polish religiosity and piety of the post-Tridentine era, combining nova et vetera, elements inherited from old centuries and entirely new. On the one hand, the religiosity of that period was based on the heritage of the late Middle Ages, on the other — it introduced elements of new piety and expanded certain forms of worship. The article describes various forms of the cult of the Passion of Christ, Calvarian devotions, ascetic practices, Marian piety and the area of hagiography. It focuses primarily on the Polish features of post-Tridentine religiosity, but also introduces the European context to indicate broader experience in this field, to draw attention to the national uniqueness and universality of Polish Catholicism, and to emphasise its dialogue with Europe.

\section{Keywords}

Post-Tridentine Catholic piety, the cult of the Passion of Christ, Calvarian devotions, ascetic practices, Marian piety, the cult of saints, hagiography

\section{Katolicka pobożność i formy kultu w potrydenckiej Rzeczypospolitej}

\section{Streszczenie}

Artykuł dotyczy polskiej religijności i pobożności doby potrydenckiej, łączącej nova et vetera elementy odziedziczone po wiekach dawnych oraz zupełnie nowe. Religijność tamtego okresu z jednej strony opierała się na dziedzictwie późnego średniowiecza, z drugiej zaś — wprowadziła elementy nowej pobożności, rozbudowała pewne formy kultu. Artykuł rejestruje różne formy kultu Męki Pańskiej, obrzędowość kalwaryjską, praktyki ascetyczne, pobożność maryjną i obszar hagiografii. Koncentruje się przede wszystkim na polskich cechach religijności potrydenckiej, ale wprowadza także kontekst europejski w celu wskazania szerszych doświadczeń w tym zakresie, zwrócenia uwagi na narodowość i powszechność katolicyzmu polskiego oraz uwydatnienia dia$\operatorname{logu}$ z Europą.

76 A. Nowicka-Jeżowa, Barok polski..., p. 169. 


\section{Słowa kluczowe}

katolicka pobożność potrydencka, kult Męki Pańskiej, obrzędowość kalwaryjska, praktyki ascetyczne, pobożność maryjna, kult świętych, hagiografia

\section{Bibliography}

Albingier E., Męczennicy jezuiccy w „Żywotach świętych” Piotra Skargi, in: Piotr Skarga - w czterechsetlecie śmierci, red. M. Kuran, M. Kuran, przy współpracy K. Kaczor-Scheitler i D. Szymczaka, Łódź 2013, pp. 259-269.

Autobiografia mistyczna Matki Teresy od Jezusa, karmelitanki bosej (Anny Marii Marchockiej) 1603-1652, red. K. Górski, (Pisarze ascetyczno-mistyczni Polski, 2), Poznań 1939.

Bania Z., Kalwarie polskie w XVII wieku. Dzieje stosowania w Europie od X do końca XVII wieku uświęconych pasją Chrystusa miar jerozolimskich, Warszawa 1993.

Bańbuła M., Bartkowski B., Gorzkie żale, in: Encyklopedia katolicka, red. L. Bieńkowski et al., t. 5, Lublin 1989, col. 1309-1311.

Barcik J., Kalwaria Pacławska, in: Encyklopedia katolicka, t. 8, red. B. Migut, Lublin 2000, col. 420-421.

Borkowska U. OSU, Hagiografia polska (wiek XVI-XVIII), in: Dzieje teologii katolickiej w Polsce, red. M. Rechowicz, cz. I, t. 2, Lublin 1975, pp. 471-503.

Bubel D., Jasnogórskie piśmiennictwo dewocyjne w XVII-XVIII wieku. Recepcja modlitewnika Ksawerego Augustyna Rottera „Ucieczka grzeszników albo nabożny zasmuconych rekurs do dzielnej cudami Częstochowskiej Matki”, "Biblioteka" 14 (2010), pp. 33-52.

Bunson M., Saint Pope Paul VI. Celebrating the 262 ${ }^{\text {nd }}$ Pope of the Roman Catholic Church, Irondale, AL 2018.

Bystroń J.S., Dzieje obyczajów w dawnej Polsce. Wiek XVI-XVIII, t. 1, Warszawa 1994.

Ceccherelli A., Od Suriusa do Skargi. Studium porównawcze o „Żywotach świętych”, tłum. M. Niewójt, Izabelin 2003.

Cieślak S. SJ, ,Harfa duchowna” — modlitewnikowy bestseller jezuity Marcina Laterny (1552-1598), "Nasza Przeszłość" 93 (2000), pp. 23-48.

Czechowicz A., Katolicyzm sarmacki, in: Humanitas $i$ Christianitas w kulturze polskiej, red. M. Hanusiewicz-Lavallee, Warszawa 2009, pp. 191-222.

Czyż A., Sarmata - niewolnik Matki. Drużbicki, Montfort i „Ogród panieński” Kochowskiego, in: Barok — sarmatyzm — „Psalmodia”. Materiaty z konferencji zorganizowanej przez Zakład historii nowożytnej, Toruń 22-23 września 1993, red. K. Maliszewski, K. Obremski, Torun 1995, pp. 7-18.

Dąbrowski S., ,Pobudka” Gorzkich żali (Próby analizy i charakterystyki), “Znak” 35 (1983), pp. 960-965.

Dobrzeniecki T., Chrystus Frasobliwy w literaturze średniowiecznej, "Biuletyn Historii Sztuki” 30 (1968) 3, pp. 279-299. 
Dobrzeniecki T., Wybrane zagadnienia ikonografii pasyjnej w sztuce polskiej, in: Męka Chrystusa wczoraj i dziś, red. H.D. Wojtyska CP, J.J. Kopeć CP, Lublin 1981, pp. 131-151.

Drogi duchowe katolicyzmu polskiego XVII wieku, red. A. Nowicka-Jeżowa, t. 7, Warszawa 2016.

Dziechcińska H., Hagiografia, in: Stownik literatury staropolskiej. Średniowiecze renesans - barok, red. T. Michałowska, przy udziale B. Otwinowskiej i E. Sarnowskiej-Temeriusz, Wrocław $2002^{3}$, pp. 298-302.

Dziechcińska H., Wzory osobowe, in: Słownik literatury staropolskiej. Średniowiecze renesans - barok, red. T. Michałowska, przy udziale B. Otwinowskiej i E. Sarnowskiej-Temeriusz, Wrocław $2002^{3}$, pp. 1060-1066.

Encyklopedia wiedzy o jezuitach na ziemiach Polski i Litwy 1564-1995, red. L. Grzebień SJ, Kraków 2004.

Estreicher K., Bibliografia polska, t. 13, Kraków 1894; t. 22, Kraków 1908.

Flaga J., Bractwa religijne w Rzeczypospolitej w XVII i XVIII wieku, Lublin 2004.

Formowanie kultury katolickiej $w$ dobie potrydenckiej, red. J. Dąbkowska-Kujko, t. 6, Warszawa 2016.

Głów K., Chrystocentryzm kultu Maryi, in: W kierunku chrześcijańskiej kultury, red. B. Bejze, Warszawa 1978, pp. 279-300.

Górski K., Borkowska A.M. OSB, Historiografia zakonna a wzorce świętości w XVII w., (Textus et Studia, 15), Warszawa 1984.

Górski K., Matka Mortęska, Kraków 1971.

Górski K., Zarys dziejów duchowości w Polsce, Kraków 1986.

Gruchała J.S., Panuś K., Wprowadzenie, in: Kazania pasyjne, red. J.S. Gruchała, K. Panuś, Kraków 2014, pp. 7-26.

Gruchała J.S., Wprowadzenie do lektury, in: A. Rożniatowski, Pamiątka krwawej ofiary Pana Zbawiciela naszego Jezusa Chrystusa, red. J.S. Gruchała, (Biblioteka Pisarzy Staropolskich, 27), Warszawa 2003.

Humanitas i christianitas w kulturze polskiej, red. M. Hanusiewicz-Lavallee, t. 4, Warszawa 2009.

Jaroszewicz F., Matka świętych Polska albo żywoty świętych, błogosławionych, wielebnych, światobliwych, pobożnych Polaków i Polek. [...] Do druku podane R.P. 1767. Przedrukowane $w$ Niemieckich Piekarach w Górnym Śląsku u Teodora Heneczka R.P. 1850.

Kaczor-Scheitler K., Mistycyzm hiszpański w piśmiennictwie polskich karmelitanek XVII i XVIII wieku, Łódź 2005.

Kaczor-Scheitler K., O kulcie maryjnym Daniela Zielińskiego w świetle „Przedmowy” poprzedzającej ,,Szatę wzorzystą doskonatości” (1649), "Respectus Philologicus” 32 (37) (2017), pp. 20-29.

Kaczor-Scheitler K., Perswazja wwybranych medytacjach siedemnastowiecznych z klasztoru norbertanek na Zwierzyńcu, Łódź 2016. 
Kanony o sakramencie matżeństwa, in: Dokumenty Soborów Powszechnych. Tekst łaciński, polski, t. 4: 1511-1870, oprac. A. Baron, H. Pietras, Kraków 2004, pp. 716-719.

Kantak K., Dzielowski Franciszek, in: Polski stownik biograficzny, red. W. Konopczyński, t. 6, Kraków 1948, p. 137.

Kicińska U., Pobożność szlachcianki w świetle polskich drukowanych mów pogrzebowych XVII wieku, "Folia Historica Cracoviensia" 18 (2012), pp. 213-237.

Kłoczowski J., Müllerowa L., Skarbek J., Zarys dziejów Kościoła katolickiego w Polsce, Kraków 1986.

Kopeć J.J. CP, Dzieje nabożeństwa Drogi Krzyżowej w Polsce, "Roczniki Teologiczno-Kanoniczne" 4 (1974), pp. 42-59.

Kopeć J.J. CP, Kalwarie i cykle Drogi Krzyżowej w kulturze polskiej oraz ich związi z topografia Jerozolimy, in: Jerozolima w kulturze europejskiej, red. P. Paszkiewicz, T. Zadrożny, Warszawa 1995, pp. 225-240.

Kopeć J.J. CP, Męka Pańska w religijnej kulturze polskiego średniowiecza. Studium nad pasyjnymi motywami i tekstami liturgicznymi, (Textus et Studia, 3), Warszawa 1975.

Kopeć J.J. CP, Nurt pasyjny w średniowiecznej religijności polskiej, in: Męka Chrystusa wczoraj i dziś, red. H.D. Wojtyska CP, J.J. Kopeć CP, Lublin 1981, pp. 38-60.

Kopeć J.J. CP, Przemiany ideowe pobożności pasyjnej na przykładzie kultu cierniowej korony Chrystusa, "Studia Theologica Varsaviensia” 10 (1972) 2, pp. 155-193.

Kopeć J., Kalwaria, in: Encyklopedia katolicka, t. 8, red. B. Migut, Lublin 2000, col. 414-420.

Korolko M., „Mąż Boleści” w staropolskich pieśniach pasyjnych, in: Chrystus w literaturze polskiej, red. P. Nowaczyński, (Zakład Badań nad Literaturą Religijną, 25), Lublin 2001, pp. 43-57.

Künstler-Langner D., Człowiek i cierpienie w poezji XVII wieku. Filozoficzne i religijne inspiracje, in: Literatura polskiego baroku w kręgu idei, red. A. Nowicka-Jeżowa, M. Hanusiewicz, A. Karpiński, Lublin 1995, pp. 257-269.

Lampen W., De spiritu S. Francisci in operibus S. Gertrudis Magnae, “Archivum Franciscanum Historicum" 19 (1926), pp. 733-752.

Lenart M., Spór Duszy z Ciałem i inne wierszowane spory w literaturze staropolskiej na tle tradycji średniowiecznej, Opole 2002.

Lewański J., Trzy modele religijnych widowisk XVII w. w Polsce, in: Dramat i teatr religijny w Polsce, red. I. Sławińska, W. Kaczmarek, Lublin 1991, pp. 33-45.

Litak S., Od reformacji do oświecenia. Kościół katolicki w Polsce nowożytnej, Lublin 1994.

Litak S., Z dziejów kultu M. Boskiej Częstochowskiej w XVII-XVIII wieku. Sprawa zasięgu społecznego, in: Z zagadnień kultury chrześcijańskiej, red. B. Bejze, Lublin 1973, pp. 447-454.

Łukarska B., Religijność sarmacka w przekazie piśmiennictwa polskiego XVII i XVIII wieku. Zarys monograficzny i antologia tekstów źródłowych, Częstochowa 2018.

Mitkowska A., Polskie kalwarie, Wrocław 2003. 
Muczkowski J., Bractwa jezuickie i akademickie w Krakowie, Kraków 1845.

Müller W., Trudne stulecie (1648-1750), in: Chrześcijaństwo w Polsce. Zarys przemian 966-1979, red. J. Kłoczowski, Lublin 1992, pp. 255-293.

Nadolski B., Liturgika, t. 2: Liturgia i czas, Poznań 1991.

Napiórkowski S.C., Chrystocentryzm myśli św. Bonawentury, "Roczniki Teologiczno-Kanoniczne" 21 (1974) 2, pp. 23-24.

Nieznanowski S., Matka Boska w poezji baroku i czasów saskich, in: Matka Boska w poezji polskiej, t. 1: Szkice o dziejach motywu, red. M. Jasińska et al., Lublin 1959, pp. 37-61.

Nowicka-Jeżowa A., Barok polski. Między Europa i sarmacją, cz. I: Profile i zarysy całości, Warszawa 2009-2011.

Nowicka-Struska A., Ex fumo in lucem. Barokowe kaznodziejstwo Andrzeja Kochanowskiego, Lublin 2008.

Nowicka-Struska A., Obrazy kobiety i kobiece wzorce osobowe w siedemnastowiecznych kazaniach pogrzebowych autorstwa karmelitów bosych, "Wschodni Rocznik Humanistyczny" 3 (2006), pp. 57-68.

On the Perfection of Life for Sisters or De perfectione vitae ad sorores, transl. P. Hanbridge OFM Cap, https://napcc.net/images/uploads/documents/De_perfectione_ vitae.pdf.

Panofsky E., Imago Pietatis. Przyczynek do historii typów przedstawieniowych Mąż Boleści i Maria Pośredniczka, in: E. Panofsky, Studia z historii sztuki, thum. i red. J. Białostocki, Warszawa 1971, pp. 95-121.

Pawlak A., ,Drogi Odkupienia...” Nabożeństwo pasyjne w Kościele polskim doby potrydenckiej na przykładzie Kalwarii Zebrzydowskiej, in: Seminaria staropolskie. Literatura w kontekstach kulturowych, red. R. Krzywy, Warszawa 1997, pp. 109-129.

Pawlak W., Bt. Stanisław Papczyński. Wśród barokowych kaznodziejów, in: S. Papczyński, Pisma pasyjne, wstęp W. Pawlak, M. Miotk CP, thum. R.R. Piętka MIC, Warszawa 2008, pp. 7-53.

Pawlak W., O wyobraźni religijnej Wespazjana Kochowskiego — „Ogród Panieński”, in: Wespazjan Kochowski w kregu kultury literackiej, red. D. Chemperek, Lublin 2003, pp. 161-183.

Pawlak W., Twórczość Wespazjana Kochowskiego wobec popularnej literatury religijnej (na przykładzie „Ogrodu panieńskiego”), in: Sarmackie theatrum. II. Idee i rzeczywistość. Materiały z konferencji naukowej, Katowice 9-11 grudnia 1998, red. R. Ocieczek, przy współudziale M. Barłowskiej, Katowice 2001, pp. 17-32.

Pirożyński M. CSSR, Obrona Jasnej Góry w roku 1655, "Homo Dei” 26 (1957) 3, pp. 359-368.

Popiołek B., Wartości religijne w mentalności kobiet z pogranicza Rzeczypospolitej w czasach saskich, in: Religijność na polskich pograniczach w XVI-XVIII wieku, red. D. Dolański, Zielona Góra 2005, pp. 287-300. 
Przybyłowicz O.M., Pobożność przedstawicielek rodów panujacych Europy Środkowej (XIII-pocz. XIV w.). Fenomen popularności franciszkanizmu: inspiracje - modele, in: Per mulierem... Kobieta $w$ dawnej Polsce - $w$ średniowieczu $i w$ dobie staropolskiej, red. K. Justyniarska-Chojak, S. Konarska-Zimnicka, Warszawa 2012, pp. 67-87.

Puchalska-Dąbrowska B.M., Bohaterowie Wysp Brytyjskich jako wzorce świętości w hagiografii polskiej XVI-XVII wieku, Białystok 2009.

Rożek M., Uroczystości w barokowym Krakowie, Kraków 1976.

Smosarski J., Z misteryjnej tradycji, "Przegląd Powszechny" 5 (1982), pp. 196-209.

Sokołowska K., Świeckich drogi do świętości whagiografii sarmacko-barokowej, Poznań 2008.

Starodawne prawa polskiego pomniki poprzedzone wywodem historyczno-krytycznym tak zwanego prawodawstwa wiślickiego Kazimierza Wielkiego, red. A.Z. Helcel, t. 1, Warszawa 1856.

Stręciwilk J. CP, Męka Pańska w polskiej literaturze barokowej, in: Męka Chrystusa wczoraj i dziś, red. H.D. Wojtyska CP, J.J. Kopeć CP, Lublin 1981, pp. 102-119.

Swastek J., Jan Kanty, in: Encyklopedia katolicka, red. S. Wielgus et al., t. 7, Lublin 1997, col. 793-795.

Ślaski J., Cesare Baronio w przekładach polskich, in: Nurt religijny w literaturze polskiego średniowiecza i renesansu, red. S. Nieznanowski, J. Pelc, Lublin 1994, pp. 365-393.

Tazbir J., Piotr Skarga - szermierz kontrreformacji, Warszawa 1983.

Tazbir J., Społeczna funkcja kultu Izydora „Oracza” w Polsce w XVII wieku, "Przegląd Historyczny" 46 (1955) 3, pp. 420-444.

Tazbir J., Święci, grzesznicy i kacerze. Z dziejów polskiej kontrreformacji, Warszawa 1959.

Teusz L., „Bolesna Muza nie Parnasu Góry, ale Golgoty”. Mesjady polskie XVII stulecia, Warszawa 2002.

Witkowska A., Nastalska J., Staropolskie piśmiennictwo hagiograficzne, t. 1: Słownik hagiografów polskich, Lublin 2007.

Wojnowski J. CSSR, Rozwój czci Matki Bożej w Polsce, "Homo Dei” 26 (1957) 6, pp. 846-862.

Wojtyska H.D. CP, Męka Chrystusa w religijności polskiej XVI-XVIII wieku, in: Męka Chrystusa wczoraj i dziś, red. H.D. Wojtyska CP, J.J. Kopeć CP, Lublin 1981, pp. 61-79.

Wolny J., Łaciński zbiór kazań Peregryna z Opola i ich zwiazek z tzw. „,Kazaniami gnieźnieńskimi”, in: Średniowiecze. Studia o kulturze, red. J. Lewański, t. 1, Warszawa 1961, pp. 171-238.

Wróbel E.E. CSFN, Życie religijne i zakonne w Polsce na przetomie XVI i XVII wieku, in: Cztery wieki Karmelitów Bosych w Polsce 1605-2005. Materiaty z ogólnopolskiego sympozjum historyczno-teologicznego, Aula Collegium Novum, Uniwersytet 
Jagielloński, Kraków 21-22 listopada 2005, red. A. Ruszała OCD, Kraków 2005, pp. 15-38.

Wyczawski H.E., Dzieje Kalwarii Zebrzydowskiej, Kraków 1947.

Wyczawski H.E., Kalwaria Zebrzydowska. Historia klasztoru bernardynów i kalwaryjskich dróżek, Kalwaria Zebrzydowska 1987.

Wydra W., Miejsce Władysława z Gielniowa w kształtowaniu się średniowiecznej poezji religijnej, in: Literatura i kultura późnego średniowiecza w Polsce, red. T. Michałowska, Warszawa 1993, pp. 69-82.

Wzorce osobowe w dawnej literaturze i kulturze polskiej, red. B.M. Puchalska-Dąbrowska, E.A. Jurkowska, Białystok 2018.

Zalewski L., Cząstka Krzyża Chrystusowego w kościele św. Stanisława OO. Dominikanów, Lublin 1946. 